\title{
Assessment of genetic variability, heterosis and heritability for morphological parameters in rice
}

\author{
Muhammad Ismaeel ${ }^{1,2 *}$, Syed Mehar Ali Shah ${ }^{1}$, Syed Suliman ${ }^{1}$, Ahmad \\ Raza $^{1}$ and Muhammad Anwar ${ }^{2}$ \\ 1. Department of Plant Breeding and Genetics, The University of Agriculture, Peshawar-Pakistan \\ 2. Agricultural Research Station Swabi, Department of Agriculture Research Khyber Pakhtunkhwa Peshawar- \\ Pakistan \\ *Corresponding author's email: ismaeelpbg@gmail.com
}

Citation

Muhammad Ismaeel, Syed Mehar Ali Shah, Syed Suliman, Ahmad Raza and Muhammad Anwar. Assessment of genetic variability, heterosis and heritability for morphological parameters in rice. Pure and Applied Biology. Vol. 8, Issue 1, pp160-168. http://dx.doi.org/10.19045/bspab.2018.700174

\begin{tabular}{llll}
\hline \hline Received: 09/08/2018 & Revised: 08/10/2018 & Accepted: 20/10/2018 & Online First: 25/10/2018 \\
\hline
\end{tabular}

\section{Abstract}

This study was performed to estimate genetic variability and heterosis in rice genotypes using fourteen parents and their ten $\mathrm{F}_{1}$ hybrids in a randomized complete block design (RCBD) using two replications at The University of Agriculture, Peshawar-Pakistan. Significant differences among the parents and $F_{1}$ hybrids were observed for all the studied traits. The parental genotypes Sadahayat, Dokri-Bas and Khushboo-95 exhibited maximum mean values for panicle length $(36.6 \mathrm{~cm})$, spikelets panicle ${ }^{-1}(264.0)$ and grains panicle ${ }^{-}$ ${ }^{1}$ (202.3), respectively while IR-8 displayed maximum mean values for 1000 -grain weight (28.7 g) and grain yield plant ${ }^{-1}$ (50.8 g). Among $\mathrm{F}_{1}$ cross combinations, DR-83/Sugdesi displayed the maximum spikelets panicle $^{-1}$ (249.1), grains panicle ${ }^{-1}$ (201.7) and grain yield plant ${ }^{-1}$ (41.8 g) while Pakhal/Kashmir-Bas displayed maximum 1000-grain weight (27.5 g). Among the $F_{1}$ hybrids, Pakhal/Kashmir-Bas manifested maximum significantly positive mid and high parent heterosis for spikelets panicle ${ }^{-1}$ (40.8 and $25.4 \%$ ), 1000-grain weight (22.7 and $14.9 \%$ ) while DR-83/Sugdesi exhibited significant positive mid and high parent heterosis for grains panicle ${ }^{-1}(66.7$ and $18.9 \%)$ and grain yield plant $^{-1}(73.8$ and $50.4 \%)$. High phenotypic and genotypic coefficient of variation (PCV and GCV) values were observed for grains panicle ${ }^{1}$ and grain yield plant ${ }^{-1}$. High heritability values were recorded for all the studied traits. The genetic potential of Sadahayat, Khushboo-95, IR-8 and Dokri-Bas for yield and yield associated traits can be exploited in future rice breeding program. The $\mathrm{F}_{1}$ hybrids viz. DR-83/Sugdesi and Pakhal/Kashmir-Bas on account of their better performance for yield and yield associated traits could be further studied in segregating generations for development of new rice cultivars.

Keywords: Genotype; GCV; Heritability; Phenotype; PCV; Rice

\section{Introduction}

Rice (Oryza sativa L.) is the main staple food for about half of the human population and occupies the pivotal place in global food and livelihood security systems. It provides $55 \%$ of the protein and $75 \%$ of the calories in the average daily diet of the people. It is globally planted on 164.1 million hectares with total production of 722.5 million tones. China (202.7 million tons), India (155.7 million tons), Indonesia (65.7 million tons), Bangladesh (50.6 million tons) and Vietnam (42.3 million tons) are the chief producing countries of rice [1]. The world's population 
is increasing at a faster rate, particularly in rice consuming countries. Almost 810 million tonnes of rice will be required to meet the growing demand of this crop by the year 2025 [2]. Rice is one of the major cereals crops of Pakistan. It is grown on 2.5 million hectares area of arable land with total production of 6.1 million tones [1]. Rice occupies an important position in the economy of Pakistan. It adds a value of 6.4 $\%$ in agriculture and contributes $1.4 \%$ to GDP of Pakistan [3].

Heterosis breeding of rice is a phenomenon in which $F_{1}$ of rice derived from different parents show superiority over their parents for various traits [4]. Furthermore, it also enriches the crops like maize, sunflower and most of the vegetables with other desirable qualitative and quantitative traits [5]. Heterosis breeding is one of the main tool of plant breeding for increasing productivity of crops [6]. In rice heterosis was first observed by Jones in 1926 who observed an increase in culm number and grain yield of the rice hybrids over their parents. Based on the criteria used to judge the hybrid performance, heterosis is expressed as mid parent heterosis, better parent heterosis or heterobeltiosis and high or standard or commercial heterosis [7]. Both positive and negative heterosis could be useful depending on the nature of a particular trait. Positive heterosis is considered desirable for yield and yield associated traits, while negative heterosis is desirable for optimum culm length, days to heading and maturity [4].

Improvement in yield and yield associated traits mainly depends on magnitude and nature of genetic variability present in a population [8]. The variations present among the genotypes of a population results due to diversity either in the genetic make-up of the genotypes of a population or in the environment in which they are grown. The existence of variation among the genotypes for the desired traits is essential for effective selection and wide adaptability. The amount of genetic variation is of paramount importance in a population for initiating a judicious breeding program [9]. Genetic parameters such as genotypic coefficient of variation $(\mathrm{GCV})$ and phenotypic coefficient of variation (PCV) are useful in detection the amount of variability present in the germplasm [10]. Higher PCV values in comparison with the corresponding GCV values for a particular trait depicts that environmental variation constitutes a major portion of the total phenotypic variance [11]. Differences between phenotypic and genotypic variance of low magnitude are indicators of additive gene action for traits expression [12]. It is very difficult to judge whether observed variation for traits of concern are highly heritable or not. Moreover, knowledge of heritability is essential for selection based improvement as it indicates the extent of transmissibility of a character into future generations [13]. Heritability is a good index of the transmission of traits from parents to offspring.

The present study was, therefore, undertaken with the following objectives:

a. To assess genetic variability for yield and yield associated traits in $F_{1}$ rice hybrids and their parents.

b. To study heterosis for yield and yield associated traits in $\mathrm{F}_{1}$.

c. To estimate heritability for yield and yield associated traits.

\section{Materials and methods}

This research work was conducted at Plant Breeding and Genetics Research Farm, The University of Agriculture, Peshawar during rice growing season 2011. The germplasm studied comprised fourteen parents and ten $\mathrm{F}_{1}$ hybrids, derived from the crosses among these parents in the preceding rice crop growing season. The list of genotypes studied is given in (Table1). First nursery was raised and then 30 days old seedlings were 
transplanted into well puddled field. A randomized complete block design with two replications was used. Each rice genotype was planted in a two-rows plot with row length of $3 \mathrm{~m}$ while row to row distance of 30 $\mathrm{cm}$ and plant to plant distance of $15 \mathrm{~cm}$ was maintained. Recommended dose of fertilizer was applied to the experimental plot and irrigation was applied frequently. Data were recorded on panicle length, spikelets panicle 1, grains panicle ${ }^{-1}, 1000$-grain weight and grain yield plant $^{-1}$ using five randomly selected plants of each entry.

\section{Statistical analysis}

Data after compilation were subjected to the analysis of the variance technique (ANOVA) as suggested by [14]. Least significance difference (LSD) test was used for means separation and comparison. Genotypic variances $(\mathrm{Vg})$, phenotypic variances $(\mathrm{Vp})$, phenotypic coefficient of variability (PCV), genotypic coefficient of variability (GCV) and broad sense heritability $\left(h^{2} B\right)$ were computed as per the method outlined by [15]. $\mathrm{Vg}=[\mathrm{MSG}-\mathrm{MSE} / \mathrm{r}]$,

$\mathrm{Vp}=\mathrm{Vg}+\mathrm{Ve}$,

$\mathrm{Ve}=\mathrm{MSE}$

$\mathrm{PCV}=\frac{\sqrt{V p}}{\bar{X}} \times 100$

$\mathrm{GCV}=\frac{\sqrt{V g}}{\bar{X}} \times 100$

Where

$\mathrm{MSG}=$ Mean squares of genotypes, $\mathrm{MSE}=$ Mean squares of error, $r=$ Number of replications, $\mathrm{Vp}=$ Phenotypic variances, $\mathrm{Vg}=$ Genotypic variances and $\bar{X}=$ Grand mean. PCV and GCV were classified either as low (less than 10), moderate (less than 20) and high (greater than 20) [16]. Broad sense heritability $\left(\mathrm{h}^{2} \mathrm{~B}\right)$ was expressed as the percentage of proportion of the genotypic variance $(\mathrm{Vg})$ to the phenotypic variance $(\mathrm{Vp})$. Heritability values were rated either as low (less than 0.30$)$, moderate $(0.30-0.60)$ or high (more than 0.60) [17].
Mid parent and high parent heterosis for each trait was determined using the following formula [18].

Mid parent heterosis $(\%)=\frac{F_{1}-M P}{M P} \times 100$

High parent heterosis $(\%)=\frac{F_{1}-H P}{H P} \times 100$

Where

$F_{1}=$ Mean of hybrid for a particular trait, $\mathrm{MP}=$ Average mean of parents for a particular trait $=\left(\mathrm{P}_{1}+\mathrm{P}_{2}\right) / 2, \mathrm{HP}=$ Mean of high parent in the cross for a particular trait, $\mathrm{P}_{1}$ and $\mathrm{P}_{2}$ are the values of a specific trait of the respective parents. The significance of $\mathrm{F}_{1}$ hybrids vs. mid parent and high parent mean was determined by t-test [19] as follows:

t-test $=\frac{F_{1}-M P}{\sqrt{3 / 8 \times E M S}}$
t-test $=\frac{F_{1}-H P}{\sqrt{1 / 2 \times E M S}}$.

Results

Panicle length

Highly significant differences $(\mathrm{p} \leq 0.01)$ among the parental genotypes and $\mathrm{F}_{1}$ hybrids were observed for this trait (Table 2). Mean data among the parental genotypes showed that panicle length ranged from 23.8 to 36.6 $\mathrm{cm}$. Among the parental genotypes, maximum value $(36.6 \mathrm{~cm})$ was exhibited by Sadahayat while the lowest value $(23.8 \mathrm{~cm})$ was observed for DR-83. Panicle length varied between 23.3 and $36.5 \mathrm{~cm}$ among the $\mathrm{F}_{1}$ hybrids. Longest panicles $(36.5 \mathrm{~cm})$ were observed for cross combination Sadahayat/Khushboo-95 while the shortest one $(23.3 \mathrm{~cm})$ was observed for cross combination DR-83/Dokri-Bas (Table 3).

Among $F_{1}$ hybrids, mid parent heterosis values ranged from -15.6 to $30.3 \%$. Four $F_{1}$ hybrids Sadahayat/Khushboo-95, DR83/Sugdesi, DR-83/DR-92 and Pakhal/Kashmir-Bas showed significant positive mid parent heterosis. DR-83/DR-92 exhibited the maximum positive mid parent heterosis $(30.3 \%)$ followed by 
Pakhal/Kashmir-Bas with mid parent heterosis of $27.3 \%$. High parent heterosis values ranged from -17.0 to $20.3 \%$ for this trait. Three $F_{1}$ hybrids viz. DR-83/Sugdesi, DR-83/DR-92 and Pakhal/Kashmir-Bas showed significant positive high parent heterosis. DR-83/DR-92 showed maximum positive high parent heterosis of $20.5 \%$ (Table 4). Moderate PCV, GCV and high broad sense heritability values of $14.9,13.9$ $\%$ and $87.2 \%$ were observed for panicle length, respectively (Table 5).

\section{Spikelets panicle ${ }^{-1}$}

Rice genotypes used in the study manifested highly significant $(\mathrm{p} \leq 0.01)$ differences for spikelets panicle ${ }^{-1}$ (Table 2). Among the parental genotypes, mean values varied from 146.7 to 239.5 for this trait. DR-83 displayed the highest number of spikelets panicle ${ }^{-1}$ (239.5), while Kashmir-Bas showed the lower number of spikelets panicle ${ }^{-1}$ (146.7). Spikelets panicle ${ }^{-1}$ ranged from 185.9 to 249.1 among the $F_{1}$ crosses. Maximum spikelets panicle ${ }^{-1}$ was recorded for DR83/Sugdesi (249.1) while minimum for DR82/IR-8 (185.9) (Table 3).

Mid parent heterosis values among $\mathrm{F}_{1}$ crosses ranged from -17.5 to $40.8 \%$ for spikelets panicle $^{-1}$. Two $F_{1}$ hybrids DR-83/Sugdesi and Pakhal/Kashmir-Bas manifested significant positive mid parent heterosis values of 15.6 and $40.8 \%$, respectively. High parent heterosis among $\mathrm{F}_{1}$ hybrids ranged from 21.5 to $25.4 \%$ in which only one cross Pakhal/Kashmir-Bas exhibited significant positive high parent heterosis $(25.4 \%)$ for spikelets panicle ${ }^{-1}$ (Table 4). Spikelets panicle $^{-1}$ manifested moderate PCV, GCV and high broad sense heritability values of $14.5,12.0$ and $68.2 \%$ (Table 5).

Grains panicle $^{-1}$

For grains panicle ${ }^{-1}$, rice parents and $F_{1}$ hybrids manifested highly significant differences $(\mathrm{p} \leq 0.01)$ (Table 2$)$. Among the parental genotypes, mean values ranged from 72.4 to 202.3 for this trait. Khushboo-95 displayed maximum (202.3) grains panicle ${ }^{-1}$ while Sugdesi manifested minimum (72.4). Grains panicle ${ }^{-1}$ among the $F_{1}$ crosses ranged from 88.5 to 201.7. Maximum value (201.7) was recorded for DR-83/Sugdesi while minimum grains panicle ${ }^{-1}$ (88.5) were observed for DR-82/NIAB-IR-9 (Table 3).

Mid parent heterosis values ranged from -1.9 to $66.7 \%$, while high parent heterosis ranged from -4.8 to $18.9 \%$ among $F_{1}$ hybrids for grains panicle ${ }^{-1}$. Only one cross DR83/Sugdesi manifested significant positive mid and high parent heterosis of 66.7 and $18.9 \%$, respectively (Table 4). Grains panicle $^{-1}$ manifested high PCV, GCV and broad sense heritability values of 24.0, 21.7 $\%$ and $80.8 \%$, respectively (Table 5).

\section{0-grain weight}

Mean squares revealed highly significant $(\mathrm{p} \leq$ 0.01 ) differences among the parents and $F_{1}$ hybrids for 1000-grain weight (Table 2). Among the parental genotypes, mean values varied between 18.3 and $28.7 \mathrm{~g}$. IR-8 displayed maximum value (28.7 g) while Sugdesi showed minimum value $(18.3 \mathrm{~g})$ for this trait. 1000-grain weight among the $F_{1}$ ranged from 19.7 to $27.5 \mathrm{~g}$. The highest value (27.5 g) was observed for cross combination Pakhal/Kashmir while the lowest 1000-grain weight (19.7 g) was observed for Sadahayat/Malhar (Table 3).

Mid parent heterosis values among rice genotypes ranged from -18.9 to $22.8 \%$ for 1000 -grain weight. Four $F_{1}$ hybrids viz. DR82/NIAB-IR-9, Sadahayat/Khushboo-95, DR-83/Sugdesi and Pakhal/Kashmir-Bas displayed significant mid parent heterosis. Pakhal/Kashmir-Bas showed maximum mid parent heterosis of $22.8 \%$. High parent heterosis of $\mathrm{F}_{1}$ hybrids for 1000-grain weight ranged from -19.0 to $14.9 \%$. Pakhal/Kashmir-Bas exhibited significant positive high parent heterosis of $14.9 \%$ (Table 6). The genotypes manifested low PCV, GCV and high broad sense heritability 
values of $11.8,9.5 \%$ and $64.4 \%$, respectively for 1000-grains weight (Table 5).

\section{Grain yield plant ${ }^{-1}$}

Analysis of variance technique (ANOVA) displayed highly significant $(\mathrm{p} \leq 0.01)$ differences among the parents and $\mathrm{F}_{1}$ hybrids for grain yield plant ${ }^{-1}$ (Table 2). Mean values among the parental genotypes varied between 23.5 and $50.8 \mathrm{~g}$. IR-8 displayed the highest grain yield plant ${ }^{-1}$ (50.8 g) while KashmirBas showed the lowest (23.5 g). Among the $\mathrm{F}_{1}$ crosses mean values for grain yield ranged from 22.2 to $41.8 \mathrm{~g}$. Maximum value ( $41.8 \mathrm{~g}$ ) was recorded for DR-83/Sugdesi while minimum grain yield plant ${ }^{-1}$ was observed by Pakhal/Kashmir-Bas (22.2 g) (Table 3).
Mid parent heterosis values for grain yield ranged from -24.7 to $73.8 \%$. Sadahayat/Khushboo-95 and DR-83/Sugdesi displayed significant positive mid parent heterosis of 38.3 and $73.8 \%$, respectively. High parent heterosis among $\mathrm{F}_{1}$ hybrids for grain yield ranged from -39.3 to $50.3 \%$. Three hybrids viz. DR-82/Shadab-31, Sadahayat/Khushboo-95 and DR-83/Sugdesi displayed significant positive high parent heterosis (Table 6). For grain yield plant $^{-1}$ high PCV and GCV values of 11.0 and $10.4 \%$ were recorded, respectively. High broad sense heritability of $89.3 \%$ was observed for the trait studied (Table 5).

Table 1. List of the rice genotypes studied during 2011

\begin{tabular}{|c|c|c|c|}
\hline \multicolumn{4}{|c|}{ Rice genotypes } \\
\hline & Parents & & Hybrids \\
\hline 1 & DR-82 & 1 & DR-82 x Sahadab-31 \\
\hline 2 & Sadahayat & 2 & DR-82 x IR-8 \\
\hline 3 & DR-83 & 3 & Sadahayat x Malhar \\
\hline 4 & Khushboo-95 & 4 & Sadahayat x Khushboo-95 \\
\hline 5 & Sathra & 5 & DR-83 x Sugdesi \\
\hline 6 & Pakhal & 6 & DR-83 x DR-92 \\
\hline 7 & Shadab-31 & 7 & DR-83 x Dokri-Bas \\
\hline 8 & IR-8 & 8 & Sathra x Sadahayat \\
\hline 9 & NIAB-IR-9 & 9 & Pakhal x Kashmir-Bas \\
\hline 10 & Sugdesi & 10 & \\
\hline 11 & Malhar & & \\
\hline 12 & DR-92 & & \\
\hline 13 & Dokri-Bas & & \\
\hline 14 & Kashmir-Bas & & \\
\hline
\end{tabular}

Table 2. Mean squares for panicle length, spikelets panicle ${ }^{-1}$, grains panicle ${ }^{-1}$, 1000-grain weight and grain yield plant ${ }^{-1}$ of $F_{1}$ 's rice along with parents during 2011

\begin{tabular}{|c|c|c|c|}
\hline \multicolumn{4}{|c|}{ Mean squares } \\
\hline Traits & Replications & Genotypes & Error \\
\hline Panicle length & 4.4 & $34.4^{* * *}$ & 2.4 \\
\hline Spikelets panicle $^{-1}$ & 188.0 & $1545.5^{* *}$ & 291.9 \\
\hline Grains panicle $^{-1}$ & 38.0 & $2520.5^{* *}$ & 267.2 \\
\hline 1000-grain weight $_{\text {Grain yield plant }}{ }^{-1}$ & 0.5 & $12.4^{* *}$ & 2.7 \\
\hline Degrees of freedom $^{* *}$ & 19.6 & $109.9^{* *}$ & 7.5 \\
\hline
\end{tabular}

$* *, *$ Significant at $\mathrm{P} \leq 0.01$ and $* \mathrm{P} \leq 0.05$ levels, respectively 
Table 3. Mean values for panicle length, spikelets panicle ${ }^{-1}$, grains panicle ${ }^{-1}, 1000$-grain weight and grain yield plant ${ }^{-1}$ of $F_{1}$ 's rice along with parents during 2011

\begin{tabular}{|c|c|c|c|c|c|}
\hline Rice genotypes & $\begin{array}{c}\text { Panicle } \\
\text { length }(\mathrm{cm})\end{array}$ & $\begin{array}{l}\text { Spikelets } \\
\text { panicle }^{-1}\end{array}$ & $\begin{array}{c}\text { Grains } \\
\text { panicle }^{-1}\end{array}$ & $\begin{array}{l}\text { 1000-grain } \\
\text { weight (g) }\end{array}$ & $\begin{array}{c}\text { Grain yield } \\
\text { plant }^{-1}(\mathrm{~g})\end{array}$ \\
\hline DR-82/Shadab-31 & 27.2 & 201.4 & 114.6 & 23.5 & 25.3 \\
\hline DR-82/IR-8 & 24.6 & 185.9 & 160.1 & 23.2 & 34.6 \\
\hline DR-82/NIAB-IR-9 & 27.2 & 209.9 & 88.5 & 24.6 & 27.4 \\
\hline Sadahayat/Malhar & 34.6 & 191.3 & 147.5 & 19.7 & 25.4 \\
\hline Sadahayat/Khushboo-95 & 36.5 & 225.7 & 192.5 & 23.6 & 40.1 \\
\hline DR-83/Sugdesi & 29.4 & 249.1 & 201.7 & 25.2 & 41.8 \\
\hline DR-83/DR-92 & 33.8 & 187.9 & 145.3 & 21.4 & 27.6 \\
\hline DR-83/Dokri-Bas & 23.3 & 236.7 & 189.4 & 24.0 & 33.4 \\
\hline Sathra/Sadahayat & 32.7 & 219.4 & 163.9 & 22.1 & 33.7 \\
\hline Pakhal/Kashmir-Bas & 34.8 & 235.2 & 87.7 & 27.5 & 22.2 \\
\hline DR-82 & 28.7 & 231.9 & 182.4 & 21.8 & 31.1 \\
\hline Sadahayat & 36.6 & 223.0 & 178.4 & 20.3 & 27.2 \\
\hline DR-83 & 23.8 & 239.5 & 169.6 & 26.8 & 27.8 \\
\hline Khushboo-95 & 26.2 & 204.6 & 202.3 & 21.8 & 30.8 \\
\hline Sathra & 26.8 & 199.1 & 155.6 & 23.6 & 33.8 \\
\hline Pakhal & 25.3 & 187.5 & 157.9 & 23.9 & 29.3 \\
\hline Shadab-31 & 26.2 & 176.1 & 147.3 & 24.4 & 35.3 \\
\hline IR-8 & 29.7 & 226.7 & 160.4 & 28.7 & 50.8 \\
\hline NIAB-IR-9 & 25.0 & 164.8 & 143.1 & 22.9 & 27.7 \\
\hline Sugdesi & 26.0 & 191.4 & 72.4 & 18.3 & 20.3 \\
\hline Malhar & 32.3 & 197.5 & 160.2 & 20.8 & 30.9 \\
\hline DR-92 & 28.0 & 215.8 & 164.9 & 26.0 & 45.5 \\
\hline Dokri-Bas & 24.1 & 264.0 & 199.5 & 23.0 & 38.3 \\
\hline Kashmir-Bas & 29.4 & 146.7 & 133.4 & 21.0 & 23.5 \\
\hline L.S.D $(0.05)$ & 3.2 & 35.4 & 33.8 & 3.4 & 5.7 \\
\hline
\end{tabular}

Table 4. Mid and high parent heterosis for panicle length, spikelets panicle ${ }^{-1}$ and grains panicle $^{-1}$ of $F_{1}$ hybrids of rice during 2011

\begin{tabular}{|c|c|c|c|c|c|c|}
\hline \multirow[b]{2}{*}{ F $_{1}$ hybrids } & \multicolumn{2}{|c|}{ Panicle length } & \multicolumn{2}{|c|}{ Spikelets panicle $^{-1}$} & \multicolumn{2}{|c|}{ Grains panicle $^{-1}$} \\
\hline & $\begin{array}{c}\text { Mid } \\
\text { parent } \\
\text { heterosis } \\
(\%)\end{array}$ & $\begin{array}{c}\text { High } \\
\text { parent } \\
\text { heterosi } \\
\text { s }(\%)\end{array}$ & $\begin{array}{c}\text { Mid } \\
\text { parent } \\
\text { heterosis } \\
(\%)\end{array}$ & $\begin{array}{c}\text { High } \\
\text { parent } \\
\text { heterosi } \\
\text { s }(\%)\end{array}$ & $\begin{array}{c}\text { Mid } \\
\text { parent } \\
\text { heterosis } \\
(\%)\end{array}$ & $\begin{array}{c}\text { High } \\
\text { parent } \\
\text { heterosis } \\
(\%)\end{array}$ \\
\hline DR-82/Shadab-31 & -0.9 & -5.0 & -1.3 & $-13.2^{*}$ & $-30.5^{* *}$ & $-37.2^{* *}$ \\
\hline DR-82/IR-8 & $-15.6^{* *}$ & $-17.1^{* *}$ & $-18.9^{* *}$ & $-19.8^{* * *}$ & -6.6 & $-12.2^{*}$ \\
\hline DR-82/NIAB-IR-9 & 1.4 & -4.9 & 5.8 & -9.5 & $-45.6^{* *}$ & $-51.5^{* *}$ \\
\hline Sadahayat/Malhar & 0.3 & -5.6 & -9.0 & $-14.2^{*}$ & $-12.9^{*}$ & $-17.3^{*}$ \\
\hline Sadahayat/Khushboo-95 & $16.2^{\text {** }}$ & -0.3 & 5.6 & 1.2 & 1.1 & -4.8 \\
\hline DR-83/Sugdesi & $18.0^{* *}$ & $13.2^{* *}$ & $15.6^{* *}$ & 4.0 & $66.7^{* *}$ & $18.9^{* *}$ \\
\hline DR-83/DR-92 & $30.3^{* *}$ & $20.5^{* *}$ & $-17.4^{* *}$ & $-21.5^{* *}$ & $-13.1^{*}$ & $-14.3^{*}$ \\
\hline DR-83/Dokri-Bas & -2.9 & -3.4 & -6.0 & $-10.3^{*}$ & 2.6 & -5.0 \\
\hline Sathra/Sadahayat & 3.0 & $-10.8^{* *}$ & 3.9 & -1.6 & -1.8 & -8.1 \\
\hline Pakhal/Kashmir-Bas & $27.3^{* *}$ & $18.5^{* *}$ & $40.8^{* *}$ & $25.4^{* *}$ & $-39.8^{* *}$ & $-44.4^{* *}$ \\
\hline
\end{tabular}

**, Significant at $\mathrm{P} \leq 0.01$ and $*, \mathrm{P} \leq 0.05$ levels, respectively 
Table 5. Genetic study of 24 rice genotypes for different traits during 2011

\begin{tabular}{|c|c|c|c|c|c|}
\hline Trait & Vg & $\mathbf{V p}$ & $\mathbf{P C V}$ & $\mathbf{G C V}$ & $\mathbf{h}^{\mathbf{2}} \mathbf{B}$ \\
\hline Panicle Length $^{-1}$ & 16.0 & 18.4 & 14.9 & 13.9 & 87.2 \\
\hline Spikelets Panicle $^{-1}$ & 626.8 & 918.8 & 14.5 & 12.0 & 68.2 \\
\hline Grains Panicle $^{-1}$ & 1126.6 & 1393.8 & 24.1 & 21.7 & 80.8 \\
\hline 1000-grain weight $^{\text {Grain yield Plant }}{ }^{-1}$ & 4.9 & 7.6 & 11.8 & 9.5 & 64.4 \\
\hline Gra $^{-}$ & 51.2 & 58.7 & 24.1 & 22.5 & 87.2 \\
\hline
\end{tabular}

Table 6. Mid and high parent heterosis for 1000-grain weight and grain yield plant ${ }^{-1}$ of $\mathrm{F}_{1}$ hybrids of rice during 2011

\begin{tabular}{|c|c|c|c|c|}
\hline \multirow{2}{*}{ F $_{\mathbf{1}}$ hybrids } & \multicolumn{2}{|c|}{$\mathbf{1 0 0 0 - g r a i n}$ weight $\mathbf{( g )}$} & \multicolumn{2}{c|}{ Grain Yield plant $^{-\mathbf{1}}$} \\
\cline { 2 - 5 } & $\begin{array}{c}\text { Mid parent } \\
\text { heterosis (\%) }\end{array}$ & $\begin{array}{c}\text { High parent } \\
\text { heterosis (\%) }\end{array}$ & $\begin{array}{c}\text { Mid parent } \\
\text { heterosis (\%) }\end{array}$ & $\begin{array}{c}\text { High parent } \\
\text { heterosis (\%) }\end{array}$ \\
\hline DR-82/Shadab-31 & 1.6 & -3.7 & $-23.8^{* *}$ & $-28.3^{* *}$ \\
\hline DR-82/IR-8 & -8.1 & $-19.0^{* *}$ & $-15.5^{* *}$ & $-31.9^{* *}$ \\
\hline DR-82/NIAB-IR-9 & $10.0^{*}$ & 7.5 & -6.8 & -11.9 \\
\hline Sadahayat/Malhar & -4.5 & -5.6 & $-12.5^{*}$ & $-17.8^{* *}$ \\
\hline Sadahayat/Khushboo-95 & $12.2^{*}$ & 8.5 & $38.3^{* *}$ & $30.2^{* *}$ \\
\hline DR-83/Sugdesi & $12.0^{*}$ & -5.8 & $73.8^{* *}$ & $50.3^{* *}$ \\
\hline DR-83/DR-92 & $-18.9^{* *}$ & $-20.2^{* *}$ & $-24.7^{* *}$ & $-39.3^{* *}$ \\
\hline DR-83/Dokri-Bas & -3.7 & $-10.6^{*}$ & 1.0 & $-12.8^{*}$ \\
\hline Sathra/Sadahayat & 0.8 & -6.1 & 10.5 & -0.3 \\
\hline Pakhal/Kashmir-Bas & $22.7^{* *}$ & $14.9^{* *}$ & $-15.9^{*}$ & $-24.2^{* *}$ \\
\hline
\end{tabular}

**, Significant at $\mathrm{P} \leq 0.01$ and $*, \mathrm{P} \leq 0.05$ levels, respectively

\section{Discussion}

Significant differences among the parents and their $\mathrm{F}_{1}$ hybrids were observed for all the traits. These results are supported with the findings of [20-24]. Four $F_{1}$ hybrids exhibited significantly positive mid and high parent heterosis for the panicle length. These results are in conformity with [21, 25]. [25] Reported mid and high parent heterosis values of 34.4 and $15.6 \%$, respectively for this trait. [21] Observed mid and high parent heterosis values of 29.7 and $28.6 \%$, respectively for panicle length. Two $F_{1}$ hybrids exhibited significantly positive mid parent heterosis while cross combination Pakhal/Kashmir-Bas manifested significantly positive high parent heterosis for spikelets panicle ${ }^{-1}$. These results are compatible with the findings of $[21,25]$. [25] Reported significant positive mid and high parent heterosis values of 56.3 and $48.7 \%$, respectively for spikelets panicle ${ }^{-1}$. [21] Reported that spikelets panicle ${ }^{-1}$ manifested significant positive mid and high parent heterosis of 110.8 and $86.3 \%$, respectively. Cross combination DR-83/Sugdesi exhibited significantly positive mid and high parent heterosis for the trait grains panicle ${ }^{-1}$. These results are in conformity with the findings of [21] who also reported significantly positive mid and high parent heterosis of 111.0 and $87.1 \%$, respectively. Four $\mathrm{F}_{1}$ hybrids displayed significant positive mid parent heterosis while one cross combination Pakhal/Kashmir-Bas manifested significant positive high parent heterosis for 1000-grain weight. $[21,26]$ reported similar results for this trait. [21] showed significantly positive mid and high parent heterosis of values 38.3 and $38.4 \%$, respectively for 1000-grain weight. In the present study two cross combinations Sadahayat/Khushboo-95 and DR-83/Sugdesi exhibited significantly positive mid and high parent heterosis for grain yield. These results are supported with the findings of $[21,26]$. [26] reported 
significant positive mid and high parent heterosis (83.7 and $67.0 \%$ ) for this trait. [21] Reported mid and high parent heterosis values of 78.9 and $60.7 \%$, respectively for grain yield plant ${ }^{-1}$.

Moderate PCV, GCV and high heritability values were observed for panicle length. [27] Reported moderate PCV and GCV values of 11.0 and $10.3 \%$, respectively while high heritability value $(86.6 \%)$ for panicle length. Moderate PCV, GCV and high heritability values for spikelets panicle ${ }^{-1}$ as observed in the present study is compatible with the findings of [28]. They also observed moderate PCV (19.0\%), GCV (14.9\%) and high heritability $(61.3 \%)$ estimates for spikelets panicle ${ }^{-1}$. High PCV, GCV and heritability values were observed for grains panicle $^{-1}$. [13] Also reported high PCV (27.0 $\%)$, GCV (25.5\%) and heritability $(89.5 \%)$ for this trait. For 1000-grain weight moderate PCV, low GCV and high heritability was observed, which are in line with the findings of [29], who also observed low PCV, GCV and high heritability values of 9.9, 9.5 and $65.5 \%$, respectively. High PCV, GCV and heritability was observed for grain yield plant $^{-1}$. [23] Also reported high PCV, GCV and heritability values of 33.3, 33.4 and 99.6 $\%$, respectively for grain yield plant ${ }^{-1}$.

\section{Conclusions}

Significant differences among the parents and $F_{1}$ hybrids were observed for all of the traits studied. Among the parental genotypes, Sadahayat, Dokri-Bas and Khushboo-95 exhibited maximum mean values for panicle length, spikelets panicle ${ }^{-1}$ and grains panicle 1, respectively while IR-8 displayed maximum mean values for 1000-grain weight and grain yield plant $^{-1}$. Cross combination DR-83/Sugdesi exhibited higher mean values for spikelets panicle ${ }^{-1}$, grains panicle ${ }^{-1}$ and grain yield plant ${ }^{-1}$ while Pakhal/Kashmir-Bas manifested maximum values for 1000-grain weight. Pakhal/ Kashmir-Bas displayed maximum positive significant mid and high parent heterosis for spikelets panicle ${ }^{-1}$ and 1000-grain weight while DR-83/Sugdesi exhibited significant positive mid and high parent heterosis for grains panicle ${ }^{-1}$ and grain yield plant $^{-1}$. High PCV and GCV values were observed for grains panicle ${ }^{-1}$ and grain yield plant $^{-1}$ while high broad sense heritability values were observed for panicle length, spikelets panicle ${ }^{-1}$, grains panicle ${ }^{-1}$, 1000-grain weight and grain yield plant $^{-1}$. Parents Sadahayat, Khushboo-95, IR-8 and Dokri-Bas on account of their genetic potential for yield and yield associated trait could be used in the future rice hybridizations. Cross combinations DR83/Sugdesi and Pakhal/Kashmir-Bas on account of their superior performance for the desired traits could be advanced to derive commercial rice cultivars.

\section{Authors' contributions}

Conceived and designed the experiments: SMA Shah, Performed the experiments: M Ismaeel \& S Suliman, Analyzed the data: S Suliman \& A Raza, Contributed materials/ analysis/ tools: M Anwar, Wrote the paper: M Ismaeel \& S Suliman.

\section{References}

1. FAOSTAT (2011) Available at http://faostat.fao.org (accessed on 01, April, 2013).

2. Hossain M, Fischer KS (1995). Rice research for food security and sustainable development in Asia: Achievement and future challenges. Geo J 35(3): 286-298.

3. FBS (2010): Federal Bureau of Statistics Government of Pakistan Islamabad.

4. Rahimi M, Rabiei B, Samizadeh H \& Ghasemi AK (2010). Combining ability and heterosis in rice (Oryza sativa L.) cultivars. J Agri Sci Tech 12: 223-231.

5. Srivastava HK (2000). Nuclear control and mitochondrial transcript processing with relevance to cytoplasmic male sterility in higher plants. Curt Sci 79(2): 176-186.

6. Alam MF, Khan MR, Nuruzzaman M, Parvez S, Swaraz AM, Alam I \& Ahsan N (2004). Genetic basis of heterosis and 
inbreeding depression in rice (Oryza sativa L.). J Zhej Uni Sci 5(4): 406-411.

7. Gupta SK (2000). In Plant Breeding: Theory and Techniques. Updesh Purohit for Agrobios, India.

8. Fisher RA (1981). The correlation among relative on the supposition of Mendelian Inheritance. Trans Roy Soci Edin 52: 314318.

9. Singh P \& Narayanam SS (2006). Biometrical Techniques in Plant Breeding, $3^{\text {rd }}$ ed. Kalyani pub New Delhi India.

10. Singh SK, Singh CM \& Lal GM (2011). Assessment of genetic variability for yield and its component characters in rice (Oryza sativa L.). Res Plt Bio (4): 73-76.

11. Sunday OF, Ayodele AM, Babatunde KO \& Oluwole AM (2007). Genotypic and phenotypic variability for seed vigour traits and seed yield in West African rice (Oryza sativa L.) genotypes. J Ame Sci 3(3): 35-41.

12. Karim D, Sarkar U, Siddique MNA, Miah MAK \& Hasnat MZ (2007). Variability and genetic parameter analysis in aromatic rice. Int J Sus Crop Pro 2(5): 15-18.

13. Sabesan T, Suresh R \& Saravanan K (2009). Genetic variability and correlation for yield and grain quality characters of rice grown in coastal saline low land of Tamilnadu. Elec $J$ Plt Bre 1: 56-59.

14. Steel RGD \& Torrie JH (1980). In: Principles and Procedures of Statistics; A Biological Approach, $2^{\text {nd }}$ ed. McGraw Hill, Inc. New York

15. Singh RK \& Chaudhary BD (1985). In: Biometrical Methods in Quantitative Genetic Analysis. Kalyani publishers, Ludhiana, India.

16. Burton GW (1952). Quantitative inheritance in pearl millet (Ptyphoides L.). Agro J 50: 503.

17. Johnson HW, Robinson HF \& Comstock RE (1955) Estimates of genetic and environmental variances in soybean. Agro J 47: 314-318.

18. Sharma GS \& Singh RB (1978). Heterosis and inbreeding depression in crossing wheat varieties of different height group. Int Agri Sci 486: 570-515.

19. Wynne JC, Emery DA \& Rice PW (1970). Combining ability estimates in Archis hypogae L. II. Field performance of $\mathrm{F}_{1}$ hybrids. Crop Sci 10: 713-715.

20. Jayasudha S \& Sharma D (2010). Genetic parameters of variability, correlation and path-coefficient for grain yield and physiological traits in rice (Oryza sativa L.) under shallow lowland situation. Elect J Plt Breeding 1(5): 1332-1338.

21. Soni S \& Sharma D (2011). Studies on heterosis for grain yield and its component traits for developing new plant type hybrids in rice (Oryza sativa L.). Elect $J$ Plt Breeding 2(4): 543-548.

22. Subbaiah PV, Sekhar MR, Reddy KHP \& Reddy NPE (2011). Variability and genetic parameters for grain yield. its components and kernel quality attriburtes in CMS based rice hybrids (Oryza ativa L.). Int J App Bio Phar Tech 2(3): 603-609.

23. Ghosh SC \& Sharma D (2012) Genetic parameters of agro-morpho-physiological traits in rice (Oryza sativa L.). Elect $\mathrm{J}$ Plt Breeding 3(1): 711-714.

24. Iftekharuddaula KM, Newaz MA, Salam MA \& Akter K (2008). Genetic analysis for panicle characters in diallel cross of rice. Bang J Agri Res 33(3): 631-638.

25. Bagheri N \& Jelodar NB (2010). Heterosis and combining ability analysis for yield and related-yield traits in hybrid rice. Int J Biosci 2(2): 222-231.

26. Islam MM, Sarker U, Rasul MG \& Rahman MM (2010). Heterosis in local boro rice (Oryza sativa L.). Bang J Plt Breeding \& Genetics 23(1): 19-30.

27. Fukrei KP, Kumar A, Tyagi W, Rai M \& Pattanayak A (2011). Genetic variability in yield and its components in upland rice grown in acid soils of north east India. $J$ Rice Res 4 (1 \& 2): 4-7.

28. Bisne R, Sarawgi AK \& Verulkar SB (2009). Study of heritability, genetic advance and variability for yield contributing characters in rice. Bangladesh J Agri Res 34(2): 175179.

29. Yadav P, Rangare NR, Anurag PJ \& Chaurasia AK (2010). Quantitative analysis of rice (Oryza sativa L.) in Allahabad agro climate zone. J Rice Res 3(1): 16-18. 